\title{
Novel $m c r-3$ variant, encoding mobile colistin resistance, in an ST131 Escherichia coli isolate from bloodstream infection, Denmark, 2014
}

L Roer ${ }^{1}$, F Hansen ${ }^{1}$, M Stegger ${ }^{1}$, UW Sönksen ${ }^{1}$, H Hasman ${ }^{1}$, AM Hammerum ${ }^{1}$

1. Department of Bacteria, Parasites and Fungi, Statens Serum Institut, Copenhagen, Denmark

Correspondence: Louise Roer (loro@ssi.dk)

A novel variant of the plasmid-borne colistin resistance gene $\mathrm{mcr}-3$ was detected on an IncHI2 plasmid in an ST131 CTX-M-55-producing Escherichia coli isolate from a Danish patient with bloodstream infection in 2014. The discovery of novel plasmid-borne genes conferring resistance to colistin is of special interest since colistin has reemerged as an important drug in the treatment of infections with multidrug-resistant Gram-negative bacteria.

Very recently, in June 2017 , Yin et al. reported a new transferable plasmid-borne colistin resistance gene, mcr-3, detected on an IncHl2-type plasmid in an Escherichia coli isolate from pig faeces in China [1]. The mcr-3 gene showed $45 \%$ and $47 \%$ nucleotide sequence similarity to $m c r-1$ and $m c r-2$, respectively [1]. Yin et al. also compared the $\mathrm{mcr}-3$ sequence to data from GenBank and found $100 \%$ nucleotide similarity to mcr-3 sequences from a porcine $E$. coli in Malaysia, a human Klebsiella pneumoniae isolate in Thailand and a human Salmonella Typhimurium in the United States. Furthermore, $99.94 \%$ nucleotide similarity was seen in two human K. pneumoniae isolates from Thailand [1].

Here we report an $m c r-3$ variant from an extendedspectrum beta-lactamase-producing (ESBL) E. coli isolated from a bloodstream infection in 2014 in Denmark.

\section{mcr-3 in ESBL/AmpC-producing} Escherichia coli isolates from human bloodstream infections and clinical carbapenemase-producing organisms

Since 2014, ESBL/AmpC-producing E. coli isolates from bloodstream infections and all clinical carbapenemaseproducing organisms (CPOs) from patients in Denmark have on a voluntary basis been referred to at Statens Serum Institut for whole genome sequencing (WGS) as part of the national surveillance programme DANMAP (www.DANMAP.org).
The $872 \mathrm{ESBL} / \mathrm{AmpC}$-producing $E$. coli isolates from human bloodstream infections collected in the years 2014 to 2016, as well as the 317 human CPOs collected from January 2014 until May 2017 were investigated in silico for the presence of $\mathrm{mcr}^{-3}$ using MyDbFinder (https://cge.cbs.dtu.dk/services/MyDbFinder/). None of the CPOs were positive for $\mathrm{mcr}-3$.

An $m c r-3$-variant was detected in one ST131 E. coli isolate (isolate id SNTR36B6, short read archive (SRA) ID ERR1971735). The isolate was obtained from a male patient admitted to hospital under the clinical diagnosis of pyelonephritis. An ESBL-producing $E$. coli with the same resistance patterns as SNTR36B6 was isolated from catheter-urine (not included in the study). The patient had no former history of hospitalisation and was without known somatic comorbidity. Upon admission, he informed about travel to Thailand two months earlier, where he had stayed locally. Antibiotic treatment with intravenously administered cefuroxime, ciprofloxacin and gentamicin was started at admission. On day 3 , the patient had fully recovered, the treatment was changed to monotherapy with perioral ciprofloxacin and the patient was discharged.

In the Sensititre broth microdilution method, the isolate, SNTR36B6, was only susceptible to piperacillin/ tazobactam, meropenem, and tigecycline and intermediate resistant to ciprofloxacin according to the European Committee on Antimicrobial Susceptibility Testing (EUCAST) breakpoints [2] (Table 1).

The ST131 ESBL-producing E. coli isolate, SNTR36B6, had $99.94 \%$ nucleotide similarity to the first $\mathrm{mcr}-3$ gene reported by Yin et al. This $\mathrm{mcr}-3$ variant differed by one amino acid (T488I) from MCR-3 (Table 2). The two Klebsiella pneumoniae with $99.94 \%$ nucleotide identity to $\mathrm{mcr}-3$ reported by Yin et al. also differed by one amino acid, but at different positions compared with the mcr-3 (D295E and G373V) in SNTR36B6 [1]. 
Sequence comparison of $m c r-3$ plasmid pWJ1 with $m c r$-3-variant of Escherichia coli patient isolate SNTR36B6, Denmark, September 2014

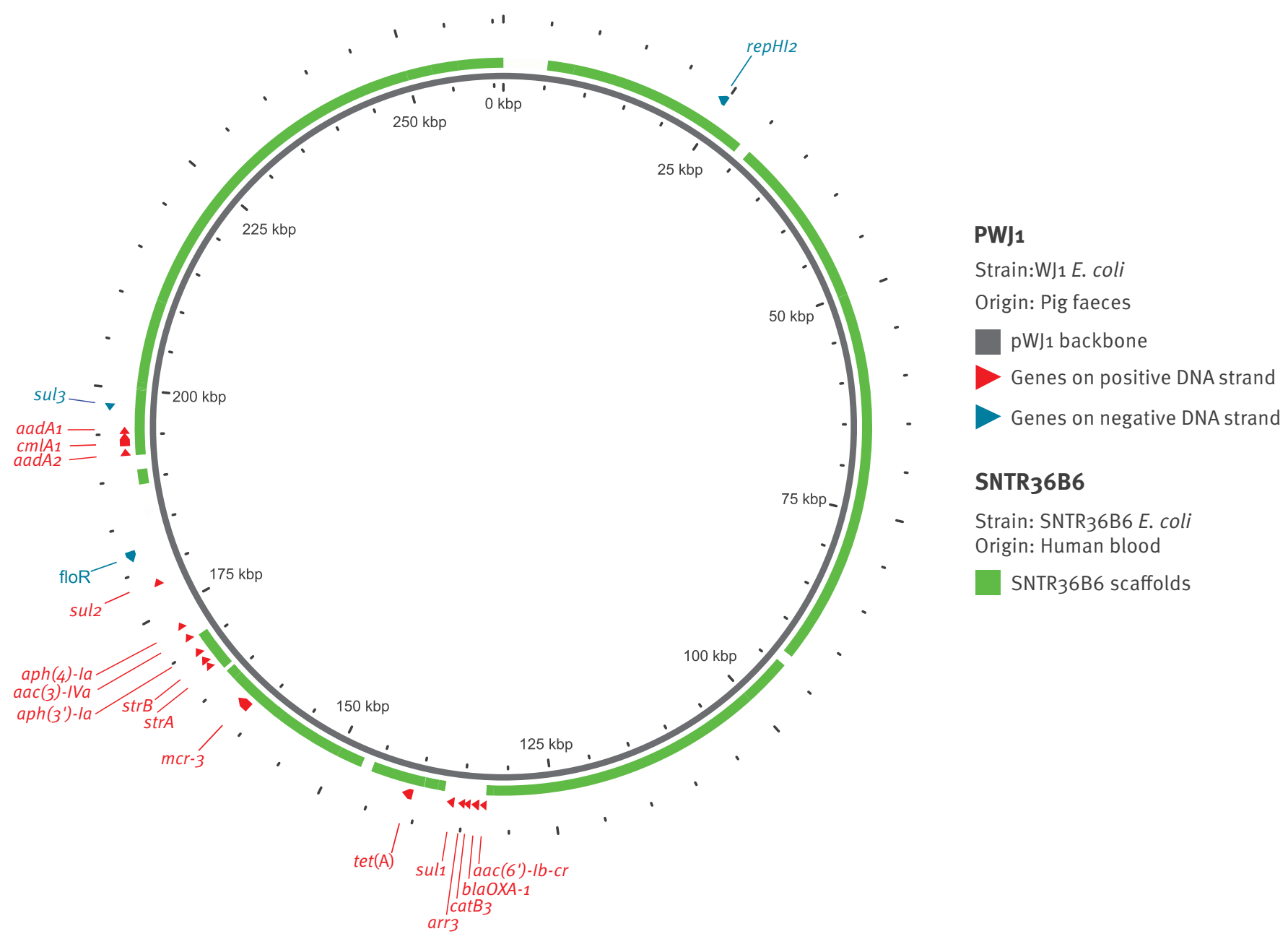

The $m c r-3$-positive $E$. coli SNTR36B6 from human bloodstream infection was compared with the $m c r-3$ plasmid pWJ1 using the GView Server. The concentric rings display similarity between the pWJ1 reference plasmid in the inner ring and the SNTR36B3 Scaffolds in the outer ring. The red and blue arrows indicate resistance genes of pWJ1, according to the orientation on the DNA strand.

Thus, the $m c r-3$ we report here is a novel $m c r-3$ variant (Table 2).

We also investigated our isolates for the presence of $m c r-1$ and $m c r-2$. None of the CPOs were positive for either gene. One ESBL-producing $E$. coli strain carried the mcr-1 gene and has been described earlier [3]. No other mcr-1-positive ESBL-producing $E$. coli were detected and none of the isolates were positive for mcr-2.

\section{Plasmid comparison to $m c r-3$ plasmid pWJ1} Besides $m c r-3$, we found 12 different resistance genes including blaCTX-M-55 and sul3 in SNTR36B6 (Table 2) using ResFinder (https://cge.cbs.dtu.dk/services/ REsfinder) [4], and SNTR36B6 was found to carry the fimH22 allele using FimTyper (https://cge.cbs.dtu.dk/ services/FimTyper/) [5].
Using PlasmidFinder (https://cge.cbs.dtu.dk/services/ PlasmidFinder/) [6], an IncHI2 replicon was detected in the WGS data from the SNTR36B6 MCR-3-producing $E$.coli isolate. The $m c r-3$ gene was initially reported to be located on a $261 \mathrm{~kb}$ IncHI2 plasmid, pWJ1, with 18 other known resistance markers [1]. BLAST analysis of the SNTR36B6 sequence against pWJ1, using the GView Server (https://server.gview.ca/), suggested a similar backbone as the pWJ1 plasmid (Figure). The sequence from SNTR36B6 had nine of its 13 resistance genes in common with $\mathrm{pWJ} 1$, while nine resistance genes were missing (Figure).

\section{Discussion}

This study is to our knowledge, the first report of $\mathrm{mcr}-3$ in E. coli outside Asia. The fact that an ST131 MCR-3producing and CTX-M-55 producing E. coli isolate was found is of particular concern, since ST131 E. coli isolates have spread epidemically during the last decade 


\section{TABLE 1}

Minimum inhibitory concentrations and resistance gene profile, ST131 Escherichia coli patient isolate carrying an $m c r-3$ variant, Denmark, September 2014

\begin{tabular}{|c|c|c|c|}
\hline Antimicrobial agent & MIC & Interpretation according to EUCAST & Associated resistance gene(s) \\
\hline Colistin & 4 & $\mathrm{R}$ & $m c r-3$ \\
\hline Piperacillin & $>256$ & $R$ & bla ${ }_{\text {CTX-M-55 }}$ \\
\hline Piperacillin/tazobactam & 2 & $\mathrm{~S}$ & None \\
\hline Cefotaxime & $>64$ & $\mathrm{R}$ & bla ${ }_{\text {CTX-M-55 }}$ \\
\hline Ceftazidime & 16 & $\mathrm{R}$ & bla ${ }_{\text {CTX-M-55 }}$ \\
\hline Cefepime & $>32$ & $\mathrm{R}$ & bla ${ }_{\text {CTX-M-55 }}$ \\
\hline Aztreonam & 32 & $\mathrm{R}$ & bla ${ }_{\text {CTX-M-55 }}$ \\
\hline Meropenem & $\leq 0.03$ & $\mathrm{~S}$ & None \\
\hline Ciprofloxacin & 0.5 & 1 & QnrS1 \\
\hline Streptomycin & 16 & a & $\operatorname{aad} A 1$, aad $A 2$, str $A, \operatorname{str} B$ \\
\hline Gentamicin & $>32$ & $\mathrm{R}$ & $\operatorname{aac}(3)-l i d, \operatorname{aph}\left(3^{\prime}\right)-/ c$ \\
\hline Tetracycline & 32 & $\mathrm{R}^{\mathrm{b}}$ & $\operatorname{tet}(\mathrm{A})$ \\
\hline Tigecycline & $\leq 0.25$ & $\mathrm{~S}$ & None \\
\hline Trimethoprim & $>32$ & $\mathrm{R}$ & $d f r A 12$ \\
\hline Sulfamethoxazole & $>1024$ & $\mathrm{R}$ & $\mathrm{sul}_{3}$ \\
\hline Chloramphenicol & 64 & $\mathrm{R}$ & $c m l A_{1}$ \\
\hline
\end{tabular}

EUCAST: European Committee on Antimicrobial Susceptibility Testing; I: intermediate; MIC: minimum inhibitory concentration; R: resistant; S: susceptible.

${ }^{\text {a }}$ No interpvretative standards.

${ }^{\mathrm{b}}$ According to the Clinical and Laboratory Standards Institute (CLSI) [16].

\section{TABLE 2}

$m c r-3$ and $m c r-3$ variants and their deduced MCR-3 and MCR-like proteins in relation to a patient isolate, Denmark, September 2014

\begin{tabular}{|l|c|c|c|c|c|c|c|c|}
\hline Species & Strain & Nucleotide ID & $\begin{array}{c}\text { Nucleotide } \\
\text { identity } \\
\text { with } m \text { cr-3 }\end{array}$ & Protein ID & $\begin{array}{c}\text { Protein } \\
\text { identity } \\
\text { with } \\
\text { MCR-3 }\end{array}$ & $\begin{array}{c}\text { Amino } \\
\text { acid } \\
\text { change }\end{array}$ & Country & Sample source \\
\hline $\begin{array}{l}\text { Escherichia } \\
\text { coli }\end{array}$ & SNTR36B6 & ERR1971735 & 99.94 & None & 99.82 & T488I & Denmark & Human blood \\
\hline $\begin{array}{l}\text { Escherichia } \\
\text { coli }\end{array}$ & pWJ1 & KY924928 & 100.00 & ASF81896.1 & 100.00 & None & China & Pig faeces \\
\hline $\begin{array}{l}\text { Escherichia } \\
\text { coli }\end{array}$ & EC15 & NZ_JWKH01000067.1 & 100.00 & WP_039026394.1 & 100.00 & None & Malaysia & Pig vulval swab \\
\hline $\begin{array}{l}\text { Salmonella } \\
\text { enterica } \\
\text { serovar } \\
\text { Typhimurium }\end{array}$ & R9_3269_R1 & NZ_NAAS01000133.1 & 100.00 & ORG07507.1 & 100.00 & None & United & Htates \\
\hline $\begin{array}{l}\text { Klebsiella } \\
\text { pneumoniae }\end{array}$ & PB533 & NZ_FLWZ01000042.1 & 100.00 & WP_039026394.1 & 100.00 & None & Thailand & Human pus \\
\hline $\begin{array}{l}\text { Klebsiella } \\
\text { pneumoniae }\end{array}$ & PB395 & NZ_FLW001000034.1 & 99.94 & WP_065801616.1 & 99.82 & D295E & Thailand & Human urine \\
\hline $\begin{array}{l}\text { Klebsiella } \\
\text { pneumoniae }\end{array}$ & PB517 & NZ_FLXA01000011.1 & 99.94 & WP_065804663.1 & 99.82 & G373V & Thailand & Human pus \\
\hline
\end{tabular}

Modified from Yin et al. [1].

${ }^{a}$ The ID number for SNTR36B6 refers to the short read archive. The other ID numbers refer to GenBank. 
and the isolate only was susceptible to very few antimicrobial classes such as carbapenems $[7,8]$.

CTX-M-55-producing E. coli isolates from humans and animals are commonly reported from Asia [9-11] but are rarely seen in Denmark. However, in 2014 and 2015, CTX-M-55-producing $E$. coli isolates were detected in respectively $3 \%$ and $5 \%$ of the ESBL/AmpC-producing E. coli from bloodstream infections [12]. CTX-M-55 producing $E$. coli isolates were also detected in $2 \%$ of the ESBL/AmpC-producing $E$. coli isolates from Danish pigs in 2015 [12].

The sul3 gene was originally detected in a porcine $E$. coli isolate from Switzerland, where 33\% of the sulfonamide-resistant porcine $E$. coli isolates carried sul3 [13]. An investigation of sulfonamide-resistant $E$. coli in Danish pigs, pork and patients from 2002 to 2003 only detected sulz in isolates from pigs and pork, but not in human isolates [14]. Between 2014 and 2016, however, the sul3 gene was detected in $1.5 \%$ of the ESBL/ AmpC-producing $E$. coli isolates from Danish patients, and was also observed in the SNTR36B6 strain in the present study.

The $m c r-3$ gene was initially reported to be located on an IncHI2-type plasmid named pWJ1. An IncHI2 replicon was also detected in SNTR36B6, and our BLAST analysis suggested that the $m c r-3$ variant could be located on a plasmid with a similar backbone belonging to this type, but this will have to be confirmed by further plasmid analysis. However, the lack in SNTR36B6 of several resistance markers which are present on $\mathrm{pW} \mathrm{J}_{1}$ suggests that the plasmid from SNTR36B6 is not completely identical to $\mathrm{pWJ} 1$.

The ST131 E. coli isolate carrying the $m c r-3$ gene variant in this study, had the fim $\mathrm{H}_{22}$ allele. Only two isolates with this allele were found among the 122 invasive $\mathrm{ST}_{131} \mathrm{ESBL} / \mathrm{AmpC}$-producing $E$. coli isolates in a study from 2017 by Roer et al. [5]. The origin of the ST131 MCR-3-producing and CTX-M-55-producing E. coli isolate is unknown, but might be related to travel to Thailand and, based on the presence of the sulz resistance gene, it might be of porcine origin.

In conclusion, with the re-emergence of colistin as an important drug in the treatment of infections with multidrug-resistant Gram-negative bacteria [15], the discovery of a plasmid-borne gene conferring resistance to colistin in an $E$. coli of human origin is of special concern. Our findings underline the usefulness of WGS-based surveillance of antimicrobial resistance for detection of new resistance genes by re-analysis of large datasets in silico.

\section{Acknowledgements}

This work was supported by the Danish Ministry of Health and Prevention as part of the Integrated Surveillance of ESBL/AmpC-producing E. coli and Carbapenemase Producing
Bacteria. We thank Karin Sixhøj Pedersen for excellent technical assistance. We would also like to thank Esad Dzajic and the staff at the Clinical Microbiological laboratory at Sydvestjysk Sygehus Esbjerg for participation in the DANMAP programme and clinical information regarding the involved patient.

\section{Conflict of interest}

None declared.

\section{Authors' contributions}

$\mathrm{LR}, \mathrm{FH}, \mathrm{HH}$ and $\mathrm{AMH}$ collected the data. LR and AMH drafted the manuscript. LR, MS, HH did the molecular analysis, UWS described the clinical data, and FH produced phenotypic data and participated in the coordination and concept of the manuscript, $\mathrm{AMH}$ coordinated the manuscript.

\section{References}

1. Yin W, Li H, Shen Y, Liu Z, Wang S, Shen Z, et al. Novel Plasmid-Mediated Colistin Resistance Gene mcr-3 in Escherichia coli. MBio. 2017;8(3):e00543-17. DOI: 10.1128/ mBio.00543-17 PMID: 28655818

2. European Committee on Antimicrobial Susceptibility Testing (EUCAST). Breakpoint tables for interpretation of MICs and zone diameters. Version 6.0. Växjö: EUCAST; 1 Jan 2016. Available from: http://www.eucast.org/fileadmin/src/media/ PDFs/EUCAST_files/Breakpoint_tables/v_6.0_Breakpoint_ table.pdf

3. Hasman H, Hammerum AM, Hansen F, Hendriksen RS, Olesen $\mathrm{B}$, Agers $\emptyset \mathrm{Y}$, et al. Detection of $\mathrm{mcr}-1$ encoding plasmidmediated colistin-resistant Escherichia coli isolates from human bloodstream infection and imported chicken meat, Denmark 2015. Euro Surveill. 2015;20(49):30085. DOI: 10.2807/1560-7917.ES.2015.20.49.30085 PMID: 26676364

4. Zankari E, Hasman H, Cosentino S, Vestergaard M, Rasmussen $\mathrm{S}$, Lund $\mathrm{O}$, et al. Identification of acquired antimicrobial resistance genes. J Antimicrob Chemother. 2012;67(11):2640-4. DOI: $10.1093 / j a c / d k s 261$ PMID: 22782487

5. Roer L, Hansen F, Thomsen MCF, Knudsen JD, Hansen DS, Wang M, et al. WGS-based surveillance of thirdgeneration cephalosporin-resistant Escherichia coli from bloodstream infections in Denmark. J Antimicrob Chemother. 2017;72(7):1922-9. DOI: 10.1093/jac/dkx092 PMID: 28369408

6. Carattoli A, Zankari E, García-Fernández A, Voldby Larsen $M$, Lund $O$, Villa L, et al. In silico detection and typing of plasmids using PlasmidFinder and plasmid multilocus sequence typing. Antimicrob Agents Chemother. 2014;58(7):3895-903. DOI: 10.1128/AAC.02412-14 PMID: 24777092

7. Price LB, Johnson JR, Aziz M, Clabots C, Johnston B, Tchesnokova V, et al. The epidemic of extended-spectrum$\beta$-lactamase-producing Escherichia coli ST131 is driven by a single highly pathogenic subclone, $\mathrm{H}_{30}-\mathrm{Rx}$. MBio. 2013;4(6):e00377-13. DOI: 10.1128/mBio.00377-13 PMID: 24345742

8. Peirano G, Pitout JD. Molecular epidemiology of Escherichia coli producing CTX-M beta-lactamases: the worldwide emergence of clone ST131 025: H4. Int J Antimicrob Agents. 2010;35(4):316-21. DOI: 10.1016/j.ijantimicag.2009.11.003 PMID: 20060273

9. Tong P, Sun Y, Ji X, Du X, Guo X, Liu J, et al. Characterization of antimicrobial resistance and extended-spectrum $\beta$-lactamase genes in Escherichia coli isolated from chickens. Foodborne Pathog Dis. 2015;12(4):345-52. DOI: 10.1089/fpd.2014.1857 PMID: 25785885

10. Xu G, An W, Wang H, Zhang X. Prevalence and characteristics of extended-spectrum $\beta$-lactamase genes in Escherichia coli isolated from piglets with post-weaning diarrhea in Heilongjiang province, China.Front Microbiol. 2015;6:1103. DOI: 10.3389/fmicb.2015.01103 PMID: 26500640

11. Xia L, Liu Y, Xia S, Kudinha T, Xiao SN, Zhong NS, et al. Prevalence of ST1193 clone and Incl1/ST16 plasmid in E-coli isolates carrying blaCTX-M-55 gene from urinary tract infections patients in China. Sci Rep. 2017;7:44866. DOI: 10.1038/srep44866 PMID: 28338012 
12. Bager F, Bortolaia V, Ellis-Iversen J, Hendriksen RS, Borck Høg $B$, Bogø Jensen L, et al. DANMAP 2015. Use of antimicrobial agents and occurence of antimicrobial resistance in bacteria from food animals, food and humans in Denmark. Søborg: National Food Institute and Copenhagen: Statens Serum Institut; 2016. Available from: http://www.danmap.org/ / media/Projekt sites/Danmap/DANMAP reports/DANMAP 2015/ DANMAP 2015.ashx

13. Perreten V, Boerlin P. A new sulfonamide resistance gene (sul3) in Escherichia coli is widespread in the pig population of Switzerland.Antimicrob Agents Chemother. 2003;47(3):116972. DOI: $10.1128 / A A C .47 \cdot 3.1169-1172.2003$ PMID: 12604565

14. Hammerum AM, Sandvang D, Andersen SR, Seyfarth AM, Porsbo LJ, Frimodt-Møller N, et al. Detection of sul1, sul2 and sulz in sulphonamide resistant Escherichia coli isolates obtained from healthy humans, pork and pigs in Denmark. Int J Food Microbiol. 2006;106(2):235-7. DOI: 10.1016/j. ijfoodmicro.2005.06.023 PMID: 16216373

15. Li J, Nation RL, Turnidge JD, Milne RW, Coulthard K, Rayner $C R$, et al. Colistin: the re-emerging antibiotic for multidrug resistant Gram-negative bacterial infections. Lancet Infect Dis. 2006;6(9):589-601. DOI: 10.1016/S1473-3099(06)70580-1 PMID: 16931410

16. Clinical and Laboratory Standards Institute (CLSI). M10o. Performance standards for antimicrobial susceptibility testing, 27th ed. Wayne: CLSI; 2017. Availale from: https://clsi.org/ standards/products/microbiology/documents/m10o/

\section{License and copyright}

This is an open-access article distributed under the terms of the Creative Commons Attribution (CC BY 4.0) Licence. You may share and adapt the material, but must give appropriate credit to the source, provide a link to the licence, and indicate if changes were made.

This article is copyright of the authors, 2017. 